\title{
OPTIMISING THE EFFECT OF CUTTING PARAMETERS ON THE AVERAGE SURFACE ROUGHNESS IN A TURNING PROCESS WITH THE TAGUCHI METHOD
}

\author{
OPTIMIZIRANJE VPLIVNIH PARAMETROV REZANJA NA \\ POVPREČNO POVRŠINSKO HRAPAVOST S TAGUCHIJEVO \\ METODO
}

\author{
Harun Akkuş \\ Amasya University, Technical Sciences Vocational School, Şeyhcui Mah. Kemal Nehrozoğlu Cad no. 92/B, Amasya 05100, Turkey \\ harunakkus@windowslive.com
}

Prejem rokopisa - received: 2018-05-30; sprejem za objavo - accepted for publication: 2018-06-28

doi:10.17222/mit.2018.110

\begin{abstract}
In this study, the AISI 1040 steel was exposed to a turning process. The experiment list was created with the Taguchi $\mathrm{L}_{16}$ experiment design based on the cutting speed, feed rate and depth of cut. The turning experiments were conducted on a CNC turning machine with a diamond cutter under dry cutting conditions. As a result of the experiments made according to the experimental design, the average surface-roughness $(R a)$ values were obtained. Signal-to-noise $(S / N)$ ratios were determined with the Taguchi analysis within the Minitab package program. According to the results, the feed rate had the most significant effect on Ra among the three factors. In an ANOVA analysis, the feed rate, depth of cut and cutting speed were effective at the $95 \%$ confidence level at the $R a$ value. During the repeated experiments carried out for the parameters chosen with the Taguchi prediction, it was clear that the Taguchi method exhibited a nearly $94 \%$ accuracy.

Keywords: optimization, turning, Taguchi method, surface roughness
\end{abstract}

Avtorji opisujejo študijo procesa struženja jekla AISI 1040. Za oblikovanje preizkusa so ustvarili Taguchi-jevo L $_{16}$ matriko, ki je temeljila na naslednjih procesnih parametrih: rezalna hitrost, hitrost odvzema materiala in globina reza. Eksperimente so izvajali na računalniško numerično kontrolirani (CNC; angl.: Computer Numerical Control) stružnici z diamantnim nožem v suhih pogojih rezanja (brez dodatnega mazanja noža). V skladu z dizajnom eksperimenta so za vsak posamezen preizkus kot rezultat dobili odgovarjajočo povprečno površinsko hrapavost (Ra). Spekter signalov oz. razmerja signal/šum ( $S / N$; angl: Signal-to-noise ratios) so določili s Taguchijevo analizo v programskem paketu Minitab. Rezultati analize so pokazali, da izmed treh analiziranih procesnih parametrov hitrost odvzema najbolj pomembno vpliva na $R a$. ANOVA analiza je pokazala, da je efektivn nivo zaupanja $95 \%$ za $R a$ vrednost pri vseh treh izbranih procesnih parametrih; to je hitrosti odvzema, globini reza in hitrosti rezanja. Ponavljajoči se eksperimenti za izbrane parametre so pokazali, da je napoved s Taguchijevo metodo približno $94 \%$ natančna.

Ključne besede: optimizacija, struženje, Taguchi, površinska hrapavost

\section{INTRODUCTION}

Due to its machining, abilities to process different materials, obtain parts with different sizes and geometries, supply the desired size accuracy and obtain clean surfaces, the turning process has been used for years and it has maintained its importance thanks to the advancing technology. ${ }^{1}$ The turning process is an important branch of machining. It can be described as a process that creates a cylindrical or rotatory shape of a material by removing the turnings from a workpiece that moves circularly. ${ }^{2}$ The workpiece constitutes the main movement by rotating. The cutting depth and the feed movement are the parameters of a machining method carried out with a cutting tool. In turning, the impact of independent variables on dependent variables is one of the factors that affects the product quality. ${ }^{3,4}$ To improve the product quality, it is important that the parameters that cause the changes in the dependent variables are researched and determined. ${ }^{5}$ In turning, the parameters like the cutting speed, feed rate, cutting depth, revolu- tion, process length, cutting tool type, material, cutting liquid, etc., represent the independent variables. ${ }^{6,7}$ The impact of these independent variables on the dependent variables like the surface roughness, abrasiveness, vibration, force, acoustic emission, etc., constitute the focal point of several researches. ${ }^{8-11}$

Detecting the surface roughness of produced parts and determining the parameters affecting the surface roughness are important for the machining. ${ }^{12}$ Estimating the surface roughness and assessing the compatibility of the processing parameters like the feed rate, cutting speed and cutting depth improve the product quality and help to obtain the desired surface roughness. ${ }^{13}$ In the researches conducted, the surface roughness decreases with an increase in the cutting speed; however, it increases with an increase in the feed rate and depth of cut. ${ }^{14}$ In machining, generally, a better surface quality is obtained at a high cutting speed. ${ }^{15}$ However, as a high cutting speed accelerates the tool wear, the same surface quality cannot be maintained for a long period of time. ${ }^{16,17}$ 
High-speed steel, cobalt-based alloys, carburized carbide, ceramic, polycrystal cubic boron nitride and polycrystal diamond glass are used as the cutting tool materials. ${ }^{2}$ For different machining applications, different tool materials are required. Before starting a process, it is important to determine the proper material and the cutting tool that will fit the material. ${ }^{18}$ After the material and the cutting tool are determined, an experimental design is carried out within the framework of the parameters that the cutting tool allows. ${ }^{19}$ During the measurement, a calibration of the measuring device is important for the measurement accuracy. The interpretation of the values obtained from the measurements made with calibrated instruments is also an important issue. ${ }^{20}$ Statistical methods, an artificial neural network, fuzzy logic, etc., are used when interpreting the experiment results. The Taguchi method is a statistical method used commonly in our research. ${ }^{21}$ It has a low-cost development cycle and it is a problem-solving tool that can enhance the product performance in the system and process design. On the other hand, the Taguchi method is a problem-solving process involving experimental and analytical concepts that determine the most effective parameters so that the results can provide significant improvements for the overall performance. For this reason, the Taguchi method uses a special design of orthogonal arrays for a study involving a process with few experiments. 22

In this study, the effect of the cutting parameters on the $\mathrm{Ra}$ values was researched experimentally using the Taguchi $\mathrm{L}_{16}$ orthogonal arrays in a turning process. The optimal cutting parameters were determined with the Taguchi analysis. Then random experiments were carried out with randomly selected parameters for the prediction. Certain percent errors between the estimation experiment and the Taguchi estimation were calculated. The results obtained are good.

\section{EXPERIMENTAL PART}

The cutting parameters were selected according to the cutting-tool manufacturer's catalog. Four levels of cutting speed $(V)$, feed rate $(f)$ and depth of cut $(a)$ were determined in the experiments. The processing conditions for the present experimental study are shown in Table 1. Figure 1 shows the cutting insert and tool holder used in the experiments. The test scheme is shown in Figure 2.

Considering the full factorial design based on the total cutting parameters specified, 64 experiments would have to be carried out. However, it would have been

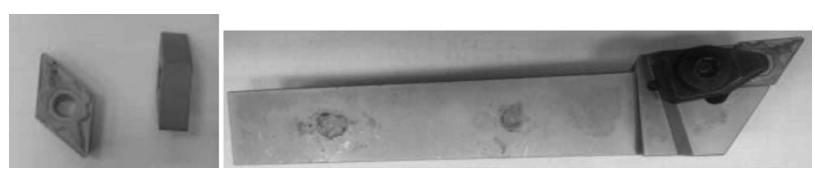

Figure 1: Cutting insert and tool holder appropriate for us to have a small number of experiments to save the time and costs. Therefore, the $\mathrm{L}_{16}$ orthogonal array was designed with the Taguchi method. The roughness device was calibrated before the measurements to allow for the measurement accuracy. The experiments were done in five replicates, and then the average of these replicates was taken. The tip used had four corners. A corner was used for each experiment. In Table 2, the experimental list generated and the average $\mathrm{Ra}$ values obtained with the measurement are given.

Table 1: Determination of the conditions for the turning process

\begin{tabular}{|c|l|l|}
\hline Number & Machining conditions & \multicolumn{1}{c|}{ Descriptions } \\
\hline 1 & Workpiece & AISI 1040 \\
\hline 2 & Workpiece hardness & $46 \mathrm{HRc}$ \\
\hline 3 & Workpiece dimensions & $\emptyset 80 \times 135 \mathrm{~mm}$ \\
\hline 4 & Processing size & $50 \mathrm{~mm}$ \\
\hline 5 & Lathe machine & $\begin{array}{l}\text { ACE Micromatic } \\
\text { Designers LT-20C }\end{array}$ \\
\hline 6 & Cutting speed $(\mathrm{m} / \mathrm{min})$ & $200-225-250-275$ \\
\hline 7 & Feed rate $(\mathrm{mm} / \mathrm{rev})$ & $0.15,0.25,0.35,0.45$ \\
\hline 8 & Depth of cut $(\mathrm{mm})$ & $1.5,2.5,3.5,4.5$ \\
\hline 9 & Cutting medium & Dry \\
\hline 10 & Inserts & $\begin{array}{l}\text { Korloy DNMG 150608 } \\
\text { diamond insert }\end{array}$ \\
\hline 11 & Tool holder & Teknik DDJNR 2525M15 \\
\hline 12 & Measurement value & $\begin{array}{l}\text { Average surface } \\
\text { roughness (Ra) }\end{array}$ \\
\hline 13 & $\begin{array}{l}\text { Roughness measuring } \\
\text { device }\end{array}$ & Mitutoyo Surftest SJ-210 \\
\hline 14 & Hardness tester & BMS Digirock RSR \\
\hline 15 & Used programs & Minitab, Excel \\
\hline 16 & Evaluation of results & Taguchi \\
\hline
\end{tabular}

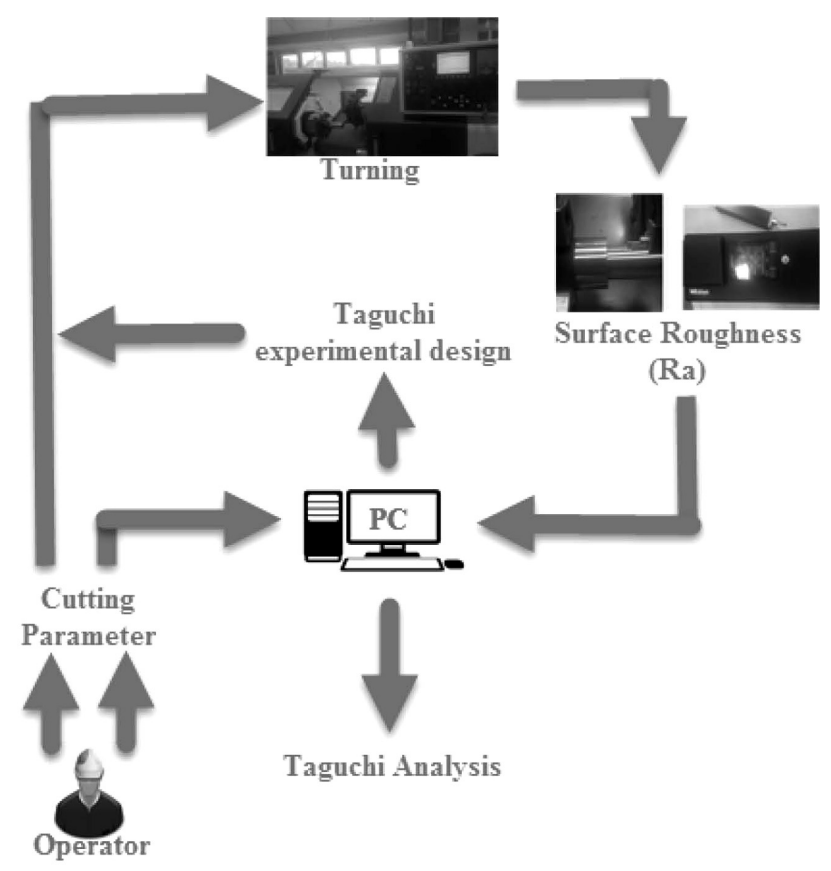

Figure 2: Experimental scheme 
Table 2: $\mathrm{L}_{16}$ design and results

\begin{tabular}{|c|c|c|c|c|}
\hline $\begin{array}{c}\text { Experimental } \\
\text { number }\end{array}$ & $\begin{array}{c}V \\
(\mathrm{~m} / \mathrm{min})\end{array}$ & $\begin{array}{c}f \\
(\mathrm{~mm} / \mathrm{rev})\end{array}$ & $\begin{array}{c}a \\
(\mathrm{~mm})\end{array}$ & $\begin{array}{c}R a \\
(\mu \mathrm{m})\end{array}$ \\
\hline 1 & 200 & 0.15 & 1.5 & 1.130 \\
\hline 2 & 200 & 0.25 & 2.5 & 2.715 \\
\hline 3 & 200 & 0.35 & 3.5 & 4.938 \\
\hline 4 & 200 & 0.4 & 4.5 & 7.695 \\
\hline 5 & 225 & 0.15 & 2.5 & 1.316 \\
\hline 6 & 225 & 0.25 & 1.5 & 2.659 \\
\hline 7 & 225 & 0.35 & 4.5 & 5.183 \\
\hline 8 & 225 & 0.4 & 3.5 & 7.444 \\
\hline 9 & 250 & 0.15 & 3.5 & 0.940 \\
\hline 10 & 250 & 0.25 & 4.5 & 2.682 \\
\hline 11 & 250 & 0.35 & 1.5 & 4.749 \\
\hline 12 & 250 & 0.4 & 2.5 & 7.252 \\
\hline 13 & 275 & 0.15 & 4.5 & 1.494 \\
\hline 14 & 275 & 0.25 & 3.5 & 2.744 \\
\hline 15 & 275 & 0.35 & 2.5 & 4.719 \\
\hline 16 & 275 & 0.4 & 1.5 & 7.048 \\
\hline
\end{tabular}

\section{RESULTS}

In the Taguchi analysis, the smaller-the-better signal-to-noise ratio was chosen to determine the best surface-roughness value. The $S / N$ ratios and level values obtained with the analysis are given in Table 3.

Table 3: $S / N$ values determined with the Taguchi method

\begin{tabular}{|c|c|c|c|c|}
\hline $\begin{array}{c}\text { Experimental } \\
\text { number }\end{array}$ & $\begin{array}{c}\text { Cutting } \\
\text { speed }\end{array}$ & $\begin{array}{c}\text { Feed } \\
\text { rate }\end{array}$ & $\begin{array}{c}\text { Depth of } \\
\text { cut }\end{array}$ & $S / N$ \\
\hline 1 & 200 & 0.15 & 1.5 & -1.06 \\
\hline 2 & 200 & 0.25 & 2.5 & -8.66 \\
\hline 3 & 200 & 0.35 & 3.5 & -13.87 \\
\hline 4 & 200 & 0.4 & 4.5 & -17.73 \\
\hline 5 & 225 & 0.15 & 2.5 & -2.41 \\
\hline 6 & 225 & 0.25 & 1.5 & -8.50 \\
\hline 7 & 225 & 0.35 & 4.5 & -14.29 \\
\hline 8 & 225 & 0.4 & 3.5 & -17.43 \\
\hline 9 & 250 & 0.15 & 3.5 & 0.54 \\
\hline 10 & 250 & 0.25 & 4.5 & -8.56 \\
\hline 11 & 250 & 0.35 & 1.5 & -13.53 \\
\hline 12 & 250 & 0.4 & 2.5 & -17.21 \\
\hline 13 & 275 & 0.15 & 4.5 & -3.46 \\
\hline 14 & 275 & 0.25 & 3.5 & -8.76 \\
\hline 15 & 275 & 0.35 & 2.5 & -13.48 \\
\hline 16 & 275 & 0.4 & 1.5 & -16.96 \\
\hline
\end{tabular}

The most basic criterion specified with the Taguchi method is the signal/noise $(S / N)$ value. The Taguchi method takes into account the high $S / N$ value to determine the optimum cutting parameters. According to this $S / N$ ratio, in the $\mathrm{L}_{16}$ orthogonal sequence, the most optimal cutting parameters from Table 3 are determined as 0.54 $S / N$ for $R a, V=250 \mathrm{~m} / \mathrm{min}$ and $f=0.15 \mathrm{~mm} / \mathrm{rev}$; when $a=3.5 \mathrm{~mm}$, the lowest $R a$ value is obtained. Table 5 shows the level values of the factors. Figure 3 shows a graph of the level values. For the experiments to be performed under the same conditions, the interpretation can be made according to the level values of the cut-off parameters shown in Table $\mathbf{4}$ and Figure $\mathbf{3}$ in order to determine the optimum cutting conditions. The third level of the cutting-speed factor, the first level of the feed-rate factor, and the third level of the depth-of-cut factor are high as shown in Figure 3 and Table 4. Therefore, the optimum cutting conditions determined under the same conditions for the experiments to be carried out are $V=250 \mathrm{~m} / \mathrm{min}, f=0.15 \mathrm{~mm} / \mathrm{rev}$ and $a=3.5 \mathrm{~mm}$. In Table 4, the cutting parameters used in the experiments show that the surface roughness is most affected by the feed rate.

Table 4: $S / N$ result table

\begin{tabular}{|c|c|c|c|}
\hline Level & Cutting speed & Feed rate & Depth of cut \\
\hline 1 & -10.331 & -1.6 & -10.014 \\
\hline 2 & -10.657 & -8.619 & -10.439 \\
\hline 3 & -9.691 & -13.793 & -9.881 \\
\hline 4 & -10.665 & -17.333 & -11.011 \\
\hline Delta & 0.974 & 15.733 & 1.13 \\
\hline Rank & 3 & 1 & 2 \\
\hline
\end{tabular}

When the optimum cutting parameters were determined with the Taguchi method, it was determined whether there was a relation between the cutting parameters and the variance analysis. The relations of the $S / N$ with the cutting speed, feed rate and depth of cut were assessed. ANOVA-analysis results are shown in Table 5. According to the ANOVA results, the significance level must be $p<0.01$ or $p<0.05$. According to these results, the most significant value order is the feed rate, depth of cut and cutting speed. The cutting speed, feed rate and cutting depth were effective at the 95-\% confidence level. At the same time, these results confirm the order of importance shown in Table 4.

The Taguchi method aims at lowering the number of experiments and acquiring reliable results in a short period. The estimation experiments carried out in this study did not take the time and cost into consideration; they were carried out to prove that the Taguchi estimation was close to the real values. In the last stage of the Taguchi analysis, estimations were made for the

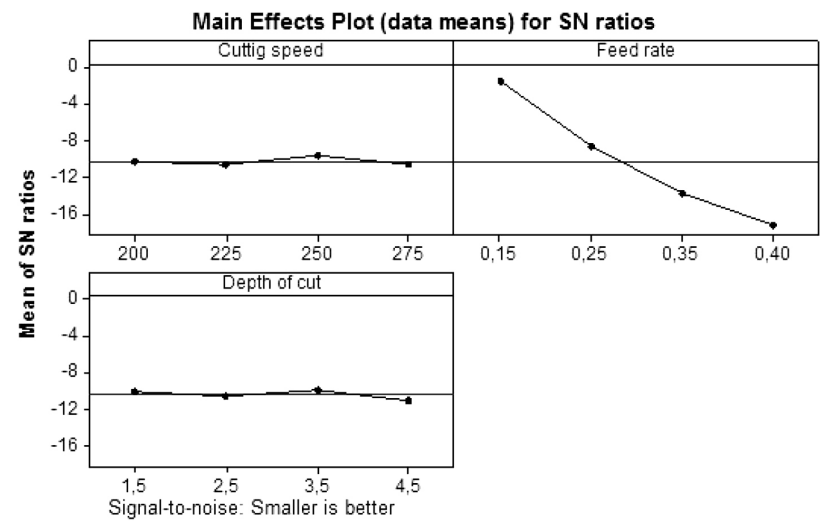

Figure 3: Factor level's Ra graphic according to $S / N$ ratios 
Table 5: Interaction between $S / N$ and cutting speed, feed rate and depth of cut

\begin{tabular}{|l|c|c|c|c|c|c|}
\hline \multicolumn{1}{|c|}{ Source } & DF & Seq SS & Adj SS & Adj MS & F \\
\hline Cutting speed & 3 & 0.1531 & 0.1531 & 0.051 & 3.15 \\
\hline Feed rate & 3 & 86.0494 & 86.0494 & 28.6831 & 1771.48 & 0.108 \\
\hline Depth of cut & 3 & 0.2879 & 0.2879 & 0.096 & 5.93 & 0.032 \\
\hline Residual error & 6 & 0.0972 & 0.0972 & 0.0162 & & \\
\hline Total & 15 & 86.5876 & & & \\
\hline
\end{tabular}

Table 6: Absolute error (\%) between the predicted results and experimental results of $R a$

\begin{tabular}{|c|c|c|c|c|c|c|}
\hline $\begin{array}{c}\text { Cutting speed } \\
(\mathrm{m} / \mathrm{min})\end{array}$ & $\begin{array}{c}\text { Feed rate } \\
(\mathrm{mm} / \mathrm{rev})\end{array}$ & $\begin{array}{c}\text { Depth of cut } \\
(\mathrm{mm})\end{array}$ & $\begin{array}{c}\text { Experimental } R a \\
(\mu \mathrm{m})\end{array}$ & $\begin{array}{c}\text { Taguchi estimated } \\
\operatorname{Ra}(\mu \mathrm{m})\end{array}$ & $\begin{array}{c}\text { Absolute } \\
\text { difference }\end{array}$ & $\begin{array}{c}\text { Absolute error } \\
(\%)\end{array}$ \\
\hline 200 & 0.15 & 4.5 & 1.28 & 1.32 & 0.04 \\
\hline 250 & 0.25 & 2.5 & 2.57 & 2.73 & 3.34 \\
\hline 225 & 0.35 & 1.5 & 4.63 & 4.86 & 0.16 & 0.22 \\
\hline
\end{tabular}

levels given in Table 6. This table lists the results of the Taguchi estimation, experimental results and the absolute errors between them given in percentages. In light of these results, the Taguchi estimation is $94-\%$ correct.

\section{CONCLUSIONS}

In this study, an analysis of the Ra values was made for the optimization of a turning process using the Taguchi experiment design. The results of the study are given below.

For the four different levels of the cutting speed, feed rate and depth of cut that were the cutting factors, an $\mathrm{L}_{16}$ orthogonal array was obtained within the MINITAB program using the Taguchi method. Thanks to this, instead of 64 full factorial experiments, 16 experiments were carried out. As the result of the experiments carried out according to the $\mathrm{L}_{16}$ orthogonal array, the $S / N$ ratio of $\mathrm{Ra}$ was found. Using the smaller-the-better $S / N$ ratio equation, the maximum value of the $S / N$ ratio was determined. The maximum $S / N$ ratio allowed the most optimal cutting parameters. For the lowest surface roughness in the turning operation, the optimal cutting conditions that corresponded to the maximum $\mathrm{Ra}$ value of $0.54 \mathrm{~S} / \mathrm{N}$ were a cutting speed of $250 \mathrm{~m} / \mathrm{min}$, a feed rate of $0.15 \mathrm{~mm} / \mathrm{rev}$ and a depth of cut of $3.5 \mathrm{~mm}$.

By applying the analysis of variance to the $S / N$ ratios, the relation levels of the cutting parameters for Ra were determined. According to the ANOVA analysis, the feed rate, depth of cut and cutting speed were effective at the $95 \%$ confidence level at the $R a$ value.

By comparing the Taguchi estimation with the experiment result, it was determined that the Taguchi estimation was approximately $94 \%$ correct.

For the subsequent studies, different materials, cutting tools, process methods, tool wears, cutting forces, vibration and acoustic-emission measurements are advised.

\section{REFERENCES}

${ }^{1}$ M. Ay, A. Turhan, Investigation of the effect of cutting parameters on the geometric tolerances and surface roughness in turning operation, Elect. Jour. of Mach. Techn., 7 (2010) 3, 55-67, doi:10.1080/ 14484846.2015.1093257

${ }^{2}$ G. S. Ahmed, S. S. H. Quadri, M. S. Mohiuddin, Optimization of feed and radial force in turning process by using taguchi design approach, Mat. Tod.: Proc., 2 (2015) 4, 3277-3285, doi:10.1016/ j.matpr.2015.07.141

${ }^{3}$ M. H. Cetin, B. Ozcelik, E. Kuram, E. Demirbas, Evaluation of vegetable based cutting fluids with extreme pressure and cutting parameters in turning of AISI 304L by Taguchi method, Jour. of Clean. Prod., 19 (2011) 17, 2049-2056, doi:10.1016/j.jclepro. 2011.07.013

${ }^{4}$ C. Camposeco-Negrete, Optimization of cutting parameters for minimizing energy consumption in turning of AISI 6061 T6 using Taguchi methodology and ANOVA, Jour. of Clean. Prod., 53, (2013), 195-203, doi:10.1016/j.jclepro.2013.03.049

${ }^{5}$ D. P. Selvaraj, P. Chandramohan, M. Mohanraj, Optimization of surface roughness, cutting force and tool wear of nitrogen alloyed duplex stainless steel in a dry turning process using Taguchi method, Measu., 49 (2014), 205-215, doi:10.1016/j.measurement.2013. 11.037

${ }^{6}$ C. J. Tzeng, Y. H. Lin, Y. K. Yang, M. C. Jeng, Optimization of turning operations with multiple performance characteristics using the Taguchi method and Grey relational analysis, Jour. of Mater. Proc. Techn., 209 (2009) 6, 2753-2759, doi:10.1016/j.jmatprotec. 2008.06.046

${ }^{7}$ S. Debnath, M. M. Reddy, Q. S. Yi, Influence of cutting fluid conditions and cutting parameters on surface roughness and tool wear in turning process using Taguchi method, Measu., 78 (2016), 111-119, doi:10.1016/j.measurement.2015.09.011

${ }^{8}$ X. Li, A brief review: acoustic emission method for tool wear monitoring during turning, Inter. Jour. of Mach. Tools and Manuf., 42 (2002) 2, 157-165, doi:10.1016/S0890-6955(01)00108-0

${ }^{9}$ K. A. Risbood, U. S. Dixit, A. D. Sahasrabudhe, Prediction of surface roughness and dimensional deviation by measuring cutting forces and vibrations in turning process, Jour. of Mat. Proc. Techn., 132 (2003) 1, 203-214, doi:10.1016/S0924-0136(02)00920-2

${ }^{10}$ H. Tebassi, M. Yallese, I. Meddour, A new method for evaluation nominal coefficient of friction and frictional forces in turning and inserts characterization using cutting forces profiles, Eng. Sol. Mech., 4 (2016) 1, 1-10, doi:10.5267/j.esm.2015.10.005

${ }^{11}$ S. A. Sajjady, H. N. H. Abadi, S. Amini, R. Nosouhi, Analytical and experimental study of topography of surface texture in ultrasonic vibration assisted turning, Mat. and Des., 93 (2016), 311-323, doi:10.1016/j.matdes.2015.12.119 


\section{H. AKKUS: OPTIMISING THE EFFECT OF CUTTING PARAMETERS ON THE AVERAGE SURFACE ROUGHNESS ...}

${ }^{12}$ J. P. Davim, A note on the determination of optimal cutting conditions for surface finish obtained in turning using design of experiments, Jour. of Mat. Proc. Techn., 116 (2001) 2, 305-308, doi:10.1016/S0924-0136(01)01063-9

${ }^{13}$ P. G. Benardos, G. C. Vosniakos, Predicting surface roughness in machining: a review, Int. Jour. of Mac. Tools and Man., 43 (2003) 8, 833-844, doi:10.1016/S0890-6955(03)00059-2

${ }^{14}$ M. Gupta, S. Kumar, Investigation of surface roughness and MRR for turning of UD-GFRP using PCA and Taguchi method, Eng. Sci. and Tech., 18 (2015) 1, 70-81, doi:10.1016/j.jestch.2014.09.006

${ }^{15} \mathrm{~W}$. Grzesik, Influence of tool wear on surface roughness in hard turning using differently shaped ceramic tools, Wear, 265 (2008) 3, 327-335, doi:10.1016/j.wear.2007.11.001

${ }^{16}$ T. Özel, Y. Karpat, Predictive modeling of surface roughness and tool wear in hard turning using regression and neural networks, Int. Jour. of Mach. Tools and Man., 45 (2005) 4, 467-479, doi:10.1016/ j.ijmachtools.2004.09.007

${ }^{17}$ M. A. Xavior, M. Adithan, Determining the influence of cutting fluids on tool wear and surface roughness during turning of AISI 304 austenitic stainless steel, Jour. of Mat. Proc. Tech., 209 (2009) 2 900-909, doi:10.1016/j.jmatprotec.2008.02.068

${ }^{18}$ S. Thamizhmanii, S. Saparudin, S. Hasan, Analyses of surface roughness by turning process using Taguchi method, Jour. of Ach. in Mat. and Man. Eng., 20 (2007) 1-2, 503-506

${ }^{19}$ W. P. Yang, Y. S. Tarng, Design optimization of cutting parameters for turning operations based on the Taguchi method, Jour. of Mat. Proc. Techn., 84 (1998) 1, 122-129, doi:10.1016/S09240136(98)00079-X

${ }^{20}$ J. T. Krishankant, M. Bector, R. Kumar, Application of Taguchi method for optimizing turning process by the effects of machining parameters, Int. Jour. of Eng. and Adv. Tech., 2 (2012) 1, 263-274

${ }^{21}$ M. Nalbant, H. Gökkaya, G. Sur, Application of Taguchi method in the optimization of cutting parameters for surface roughness in turning, Mat. and Des., 28 (2007) 4, 1379-1385, doi:10.1016/ j.matdes.2006.01.008

${ }^{22}$ İ. Tekaüt, M. Günay, U. Şeker, Optimization of cutting parameters and chip breaker form by Taguchi method in turning operations, $6^{\text {th }}$ Int. Adv. Tech. Symp., 2011, 127-131 